too much-he suffers no inconvenience, though at one time it seemed almost certain that a stricture would be formed, but this has been prevented by the daily passage of the finger. Another point worth noticing is the fact that though the internal sphincter muscle was completely divided, the patient has now entire control over the bowel, the contraction of both sphincter muscles being extraordinarily good.

From the medical aspect there can, we think, be no doubt that in this case the symptoms were due to the presence of lardaceous degeneration of the kidney. 'The marked cedema, the abundant urine of clear and non-albuminous appearance, the enormous amount of albumin, together with the total absence of casts, all point in this direction. Further, the presence of the more usual forms of nephritis is excluded by the normal condition of the heart and vessels. Reduplication of the first and accentuation of the second sound were altogether absent, and there was no hypertrophy of the left ventricle. The pulse, too, was very far from presenting the qualities found to characterise chronic renal disease.

The case seems to be an important one in the light of the difference of opinion which exists concerning the nature of the renal lesion which accompanies tuberculosis. Quite recently Dr. Landouzy and Dr. Bernard ' published a paper in which they upheld a contention that tuberculosis, pulmonary and other, acts on the kidneys through the effect of the toxins which appertain to the activity of the tubercle bacillus. These authors maintain that the bacillus has no direct action on the kidney structure, but that a chronic inflammatory process is engendered by the "toxin" of the bacillus which eventuates in a chronic parenchymatous nephritis. Quite opposed to this view is that of Dr. A. Brault $^{2}$ who strongly criticises the argument of Dr. Landouzy and Dr. Bernard. He says that there is no evidence whatever of the existence of such a form of nephritis as that described by the writers just named. Dr. Brault attributes all the symptoms referred to by Dr. Landouzy and Dr. Bernard as being the result of the presence of amyloid disease of the kidney. He points out, further, that the so-called "large white kidney" of old days is neither more nor less than this same lardaceous degeneration of the organ. We are in entire accord with Dr. Brault on this subject. We do not accept the arguments which would attribute to tuberculosis of the lungs and other organs the power of initiating kidney changes which are sui generis and are due to the action of a "toxin" of which nothing is known. But as for the "large white kidney"-_a term happily now nearly extinct-we have no doubt at all that it is merely a more or less marked form of amyloid renal disease. It will be noticed that in the present case the symptoms are just those which were formerly attributed to the presence of the "large white kidney"-viz., large quantities of urine and of albumin, much cedema, and considerable pallor. The presence of tuberculous disease no doubt accounts for the lardaceous degeneration of the kidneys, a condition comparatively rare and one which has given rise to great errors, both as regards pathology and diagnosis. For this reason we think that the present case is one of some importance as elucidating a form of renal disease which has given rise to much misconception.

1 La Presse Médicale, March 16th, 1901. 2 Ibid., April 6th, 1901

Infantile Mortality at Bath.-At the meeting of the Bath Sanitary Committee held on June 24th the medical officer of health reported that he had caused leaflets to be distributed in regard to the treatment of children in the city. Dr. Symons added that 31 children had died from diarrhce in 1898 and 30 in 1899, whereas in 1900 only five deaths had occurred from the disease.

Distribution of Charitable Funds. - The assistant commissioner of charity inquiries (Mr. Cardew) has been holding investigations in connexion with the charities of villages near Devizes. At Rowde, one charity bequeathed in 1715 was stated to be disbursed in payments of $8 d$. each to 492 applicants. Mr. Cardew urged the adoption of some different method of distributing the money, such as contributing to a local hospital where the parishioners in need of medical and surgical treatment could receive treatment.

\section{THE PHYSICAL CAUSES OF THE SLIGHTER FORMS OF MENTAL DEFECTS IN CHILDREN.'}

\author{
BY FRANK M. POPE, M.D.
}

IN 1899 the Elementary Education (Defective and Epileptic Children) Act was passed, entitled, "An Act to make better provision for the Elementary Education of Defective and Epileptic Children in England and Wales." This Act empowers school authorities (1) to ascertain what children in their district not being merely dull or backward and not being imbecile are defective-that is to say, what children by reason of mental or physical defect are incapable of receiving proper benefit from the instruction in public elementary schools, but are not incapable by reason of such defect of receiving benefit from instruction in special schools; and (2) what epileptics are capable of receiving benefit. The State thus did for mentally defective children what it had previously done for the deaf and dumb and the blind.

The duty of deciding as to what children came under the above definition was given to approved medical men, examination by whom was made compulsory, and the school age of such children was raised to 16 years. I was appointed to act in this manner for the Leicester School Board and have in consequence examined a large number of children. After doing this I looked up the literature on the subject, more particularly the work ${ }^{2}$ and reports ${ }^{3}$ referred to below, and Dr. F. Warner's article in "Allbutt's System of Medicine." In the report of the Committee there is an immense mass of statistics, over 100,000 children of every degree of mental capacity having been examined. The direction the inquiry had taken was mainly that of observing the conditions of the children with regard to bodily development and defects. The former was in many cases found to be imperfect and the latter were frequent, and the conclusion sought to be enforced appeared to be that the physical defects and socalled abnormal nerve signs were on the whole an index of the accompanying mental defect if any. Abnormal nerve signs are the conditions of expression, tone of facial muscles, "position of hands," tremor, "response to action," and others, and the remark is made that observers in this field must depend for any good results on inspection mainly, this being thought to give better results than the appraisement of the mental deficiency by interrogation of the child. The physical defects to which the observers attached most significance were cranial abnormalities-large heads, small heads, cranial bọsses (rickets), defect of forehead, frontal ridges, and head asymmetrical ; defective ears (external) ; palate-higharched, V-shaped, cleft and others; defective nasal bones and general debility. The correlation of these two classes of signs is made the criterion of mental defect. I reserve my criticisms on these reports till later, only remarking here (1) that Dr. Warner acknowledges that some dull children have no defect and that some children with these signs are not dull ; (2) that there is an underlying assumption throughout the report that these signs are those of degeneration; and (3) that Dr. Warner says that these signs appear to be inherited. Their conclusions appear to be mainly that physical conditions are an index of mental ones, that both should be looked for, and that no risk should be run of neglecting children who exhibit defects. As a practical outcome of the Committee's labours the Act of 1899 was passed. I do not know that one can blame these committees for not having investigated the causes of such defects. If it was the case that they did not examine the children closely, as for cardiac defects and the like, and that they were not supplied with family histories, it is obvious that they were not in a position to undertake the inquiry. Under the Act of 1899 the medical officers have the opportunities which were wanting to these committees. The parents are usually seen and the children can be closely and carefully examined. After making many

I Thesis for degree of M.D. in the University of Cambridge 2 Shuttleworth : Mentally Deficient Children, second edition (Lewis,

3 Report on the Scientific Study of the Mental and Physical Conditions of Childhood (Charity Organisation Society, London, 1895).

4 Clifford Allbutt: A System of Medicine, vol. viii. (London Macmillan, 1899). 
such examinations it appears to me that it would be possible to inquire more closely into the pathological causes of the mental defects presented by the children with a prospect of arriving at some definite conclusions. I therefore undertook further inquiries into the subject, the results of which $I$ here present.

I have examined about 120 children in the schools of the Leicester School Board. These children were most of them already in the special classes for defective children, having been found, by the teachers in the first place, and by the inspector, a man of great experience-Mr. $\mathrm{H}$. Major, B. Sc. Lond. - in the second, to be unfit for the ordinary school work. All children examined were admittedly defective mentally. Thus by rule of thumb the special class desired had been already weeded out and the medical examination could be directed to ascertaining if any were either mentally so deficient that it was useless to expect any improvement under education, or, on the other hand, if there were any whose defect was not marked enough to prevent their being. placed in the ordinary classes. In most cases the mother and the teacher were present at the examination of the child, so that the family history could be inquired into, and crossexamination (which is most necessary) could be practised. When I found that it was possible that some light might be thrown on the etiology of these mental defects by the facts which I had ascertained by leave of the London School Board I obtained access to the reports of about 200 of the defective children in their schools, and the result of this examination is included with my own results. In addition, I made observations on 500 children in the upper fifth, sixth, and seventh standards of the Leicester board schools, with a view of seeing if any of the defects supposed to indicate mental deficiency were present in those presumably the brightest of the scholars. It was my original intention to have excluded what are usually termed imbeciles from my statistics, but I soon found that apart from the difficulty of drawing a hard-andfast line between these and the simply defective cases it was probable that they differed only in degree from the milder cases, and the causes producing the defective condition were probably alike in all. A certain proportion of the imbeciles and idiots are besides excluded from most of the statistics by the separation of the hereditary from the non-hereditary cases. It seemed probable that some of the causes producing insanity would also operate in those minor defective mental states (of course, excluding causes such as intemperance, \&c., acting in the lifetime of the insane person), and of these that heredity would be one of the most important. Maudsley 5 says of the causes of idiocy that many of them operate after birth; they are epilepsy, the acute exanthemata, perhaps syphilis, and certainly starvation, diet, and overcrowding. Shuttleworth gives an excellent résumé of the various factors of causation. I need not enumerate them, as I shall take his list as the basis of classification of my own cases (see also Ireland ${ }^{6}$ )

Heredity. - In the insanity of adults, in idiocy, and in imbecility there is no doubt that one of the most important causes is heredity. If to those cases having a clear history of insanity in the family we add those having a clear history of epilepsy we get a considerable proportion of cases of mental weakness accounted for. These cases are also in the truest sense of the word hereditary, for we can hardly conceive of the transmitted defect, be it what it may, as anything other than one which is of the essence of the organism, and as being present in the germ or sperm cell, and hence not only as having been transmitted, but as being also transmissible to future offspring. The question of the part played by heredity in insanity has been often fully treated, and I therefore consider mrself justified in excluding altogether from the scope of my inquiry, at any rate as far as numbers and conclusions arrived at from numbers are concerned, all cases where a clear family history of insanity or epilepsy in the family can be ascertained. I therefore allow that a percentage of perhaps about 30 of the cases of mental deficiency which are being treated in special classes are dne to inherited defect from insare or epileptic parents, and I am only attempting to show the causation of the remainder (perhaps 70 per cent.). I have satisfied myself, as far as the cases which I myself have examined, that I have excluded heredity, but with regard to the London cases I fancy that the family histories were not complete in all instances. As, however, the exclusion of some hereditary cases will tell against and not for my conclusions, such accidental inclusion will really strengthen my arguments.

Development of brain. - I need not enter very fully into the manner in which the brain is developed. After the hindbrain, with its centres for respiration and circulation, is developed, great tracts having for their function the placingof the hemispheres and subjacent great ganglia in communication with the organs of special sense and the tactile sensory system have to be elaborated, and the great motor tracts placing the hemispheres in connexion with the locomotor apparatus have to be formed, and pari passu with these growths are built up the cerebellar and other controlling mechanisms. Lastly, in the cerebrum there appears to go on for the greater part of life a linking up of the higher centres, making certain paths easier and possibly, but not so certainly, other paths more difficult, for nervous impulses to traverse. For the proper working of even the very lowest degree of human intelligence a comparatively high development of the central nervous system is necessary. The sense organs must be developed and intact, their sensoria developed and intact, the efferent apparatus for expression, whether lingual or cheirokinæsthetic, developed and intact, and the connecting links, if not all completely developed, must at any rate be in a condition allowing of development. By the time a child has reached an educable age it is probable that little difference could be distinguished histologically between the brain of such child and that of a man aged 25 years. ${ }^{7}$ It is obvious that in the course of the growth of such a complex organ the possibilities of interference with its proper development are very numerous and that such interference may take place at any time. We are familiar with teratological monstrosities in which the hemispheres are undeveloped, with idiots in whom we can find every variety of arrested development-brains with few convolutions, non-development of optic or auditory tracts, and the rare cases of non-development of the pyramidal tracts. Shuttleworth divides his cases into congenital and non-congenital, and places between these a mixed class which he terms "developmental." This is, of course, a classification of utility only. The defect arising from an injury to the foetus by the mother falling down stairs is precisely comparable to that due to the child of a few months being dropped, and so is intra-uterine to extra-uterine small-pox. I propose, however, to follow him to some extent and to classify the causes of mental defects into ante-natal. natal, and post-natal causes.

General mental condition of cases examined. - The children whose examination forms the basis of these statistics varied considerably in mental power. Some, as has been stated, were imbeciles, but capable of speech and of some amount of education, and from these the gradation could be traced up to the child who after a few months' training in the defective children's class was able to join normal children of a somewhat younger age. Moral defect was uncommon among them and except in the hereditary cases it was not usual to find them troublesome to their teachers. Perhaps the best way to describe them is to say that before special training they are about equal mentally to children of the age of four or five years. They lack the power of concentration of thought and, as a rule, cannot reckon except in very low numbers. Their imitative powers are weak, hence they seldom write or draw well.

Method of investigating the causes of the mental defocts. - A few words are necessary as to the method by which the assigned causes of mental deficiency were ascertained. Two returns on forms prescribed by the Education Department were filled up for each child, one by the teacher of the class in which the child was and the other by a parent and the teacher corjointly. The latter contains statements of age of parents, their mental condition. condition as to temperance, cause of death if not living, ages and states of health of living brothers and sisters, and causes of, and ages at death of, deceased ones: whether insanity, fits, consumption, or scrofula existed in the family; the time when the mental deficiency of child was first observed; the cause to which it is attributed, and other facts. Taking these as a basis, the mother in most cases, the father or other near relative in a few, was seen and questioned. especially as to the time when the deficiency was first observed and the causes assigned for it, and care was taken that at least no cause was put down as probable unless it had preceded 
in time the observed mental deficiency. The mere fact of such a disease as measles being assigned by a mother as a cause was not thought to justify its inclusion unless it was expressly stated that the child was very seriously ill at the time, or unless the complications or sequelæ of the diseasee.g., long insensibility, aural or ophthalmic trouble-gave some colour to the assertion, and so with other assigned causes. In most cases the mothers were intelligent women, and it is difficult to see whose opinion could be taken in preference to theirs, as a complete medical life-history written by a medical man was impossible to be obtained. The mothers had no pre-existing ideas on the subject, and I think I shall show that in most instances the canses which ther assigned had much to do with the arrest of brain development in the children.

Classification of alleged causes. - Ante-natal : hereditary brain disease or epilepsy, defects of orum (syphilis?), parental intemperance, age of mother, twin pregnancy, and intra-uterine acciclents (injury to mother, fright to mother, intra-uterine diseases). Natal: Causes acting at time of birth-premature birth, lingering labour, and ophthalmia. Post-natal : accidents-injury to brain, injnry to organs of special sense, and injury to body generally. Diseases of brain, \&c. : meningitis, hydrocephalus, epilepsy, convulsions, chorea, and hæmorrhage (apoplexy). Maldevelopment in some definite area-e.g., Broca's. Disease of the spinal cord: Friedreich's disease. Diseases of special senses: the eye, the ear, the nose and pharynx, and the nose and adenoids. Bacterial diseases: whooping-cough, measles, scarlet fever, typhoir fever, diphtheria, and fever. Diseases of the lungs: bronchitis, pleurisy, and pneumonia. Diseases of the heart and of the kidneys. General diseases: rickets, cretinism, tubercle, rheumatism, debility, want of appetite, \&c., diseases of skin, eczema, \&c. This is a very long list, and it covers most of the diseases of children that are known to medicine. I hope to show, however, that most cases are not due to the operation of one cause alone, with the exception of some of those due to hereditary brain clisease and the obvious ones of accident or acute brain disease, such as hydrocephalus.

Hereditary cases.-After excluding some children who were not defective, and three or four in whose cases the cause was severe injury to the head in childhood, there remain for the purposes of my statistics 104 cases. Of these, .28, or 26.9 per cent., had relatives who were either insane or epileptic. These were grouper as follows: epilepsy in family, eight; insanity, 10 ; imbeciles and idiots, four; intemperate parents, three; and syphilis, one. The last two items require explanation. The parental intemperance was very marked in these cases, and it was almost certain that the parents were mentally of a very low type. Syphilis was placed here because it is so clearly an hereditary disease, and it is obvious that the age of the mother could exercise no effect on its transmission.

Reasons for believing the causes probable. - With regard to the second group of cases, where hereditary brain disease was not shown to exist, 76 , or 73.1 per cent., of my cases were carefully examined, and I satisfied myself as far as possible that the causes given by the mothers as probable did correspond fairly well in the time of their occurrence with the time when mental deficiency was first noticed. With regard to the 151 cases in the London board schools of which I have copied the notes I am not in a position to say as much; I have therefore not included these with my own cases, but have quoted them separately. The close agreement in the percentages of the two series is remarkable, and it strengthens the probability that the causes given are true and not merely apparent. (No hereditary cases are included in the London series.)

\section{AGE OF Mother.}

Before directing attention to Table I. on which I have tabulated the different canses, giving my own results in the first column and those from the London School Board in the second, I must explain that I leave for subsequent discussion what I have reason to consider the most important and frequent cause of all-namely, an advanced age of the mother at the birth of the child. I mention it here because this cause must act on the ovum from its earliest age-that is if we leave out such questions as that of prolonged labour and lacteal supply, and therefore it should be grouped with the ante-natal causes. To consider the other causes seriatim.

Syphilis.-I only found undoubted hereditary syphilis in one case. This is rather surprising, but it is borne out by the fact that only one of the London cases was assigned to this cause. Hutchinson has noted the same fact among patients at Earlswood. ${ }^{\circ}$

Parental intemperance. (No evidence of hereditary brain disease. )-This is a very difficult subject on which to express an opinion. I have already given reasons for including among hereditary cases the four cases from Leicester in which this cause was assigned. If these reasons are admitted as valid there remains no case in which it is

TABLE I.-Sohedule of Causes.

\begin{tabular}{|c|c|c|}
\hline & $\begin{array}{l}\text { Of my } \\
\text { own } 76 \\
\text { cases. }\end{array}$ & $\begin{array}{l}\text { Of } 151 \\
\text { London } \\
\text { cases. }\end{array}$ \\
\hline \multirow{2}{*}{$\begin{array}{l}\text { Ante-natal causes- } \\
\text { Syphilis } \quad \ldots \quad \ldots\end{array}$} & & \\
\hline & 1 & 1 \\
\hline 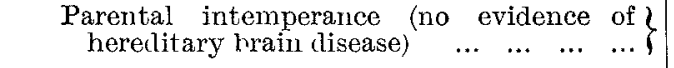 & 4 & $2 ?$ \\
\hline $\begin{array}{llllllll}\text { Twin pregnancy } & \ldots & \ldots & \ldots & \ldots & \ldots & \ldots & \ldots\end{array}$ & 1 & 1 \\
\hline 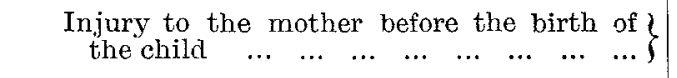 & - & 4 \\
\hline $\begin{array}{l}\text { Fright to the mother before the birth of the } \\
\text { child } \\
\ldots\end{array}$ & 2 & 2 \\
\hline Intra-uterine diseases (congenital cataract) & 2 & 1 \\
\hline \multicolumn{3}{|l|}{ Natal- } \\
\hline $\begin{array}{llllllll}\text { Premature birth } & \ldots & \ldots & \ldots & \ldots & \ldots & \ldots & \ldots\end{array}$ & 1 & 1 \\
\hline $\begin{array}{l}\begin{array}{l}\text { Lingering labour } \\
\ldots\end{array} \\
\text { Post-natal一 }\end{array}$ & - & 2 \\
\hline $\begin{array}{llllllll}\text { Injury to brain } & \ldots & \ldots & \ldots & \ldots & \ldots & \ldots & \ldots\end{array}$ & 2 & 2 \\
\hline 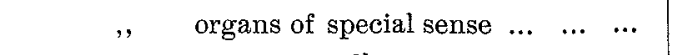 & - & 1 \\
\hline 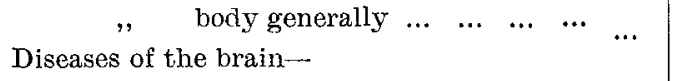 & Diseases of the brain- & 2 \\
\hline Meningitis or "inflammation" $\quad \ldots \quad \ldots \quad \ldots$ & - & 3 \\
\hline $\begin{array}{llllllll}\text { Hydrocephalus } & \ldots & \ldots & \ldots & \ldots & \ldots & \ldots & \ldots\end{array}$ & 3 & 1 \\
\hline $\begin{array}{llllllllll}\text { Epilepsy } & \ldots & \ldots & \ldots & \ldots & \ldots & \ldots & \ldots & \ldots & \ldots\end{array}$ & 9 & 8 \\
\hline $\begin{array}{lllllllll}\text { Convulsions } & \ldots & \ldots & \ldots & \ldots & \ldots & \ldots & \ldots & \ldots\end{array}$ & 6 & 10 \\
\hline $\begin{array}{llllllllll}\text { Chorea } & \ldots & \ldots & \ldots & \ldots & \ldots & \ldots & \ldots & \ldots & \ldots \\
\end{array}$ & 3 & 3 \\
\hline $\begin{array}{llllll}H & \ldots & \ldots\end{array}$ & 4 & 4 \\
\hline $\begin{array}{l}\text { Defect of the speech area (cause } \\
\text { Diseases of the spinal cord- }\end{array}$ & 2 & - \\
\hline 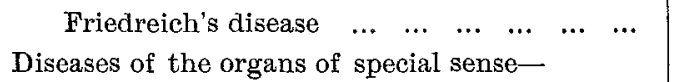 & Diseases of the organs of special sense- & 1 \\
\hline $\begin{array}{llllll} & \text { Eye }(\text { blind cases excluded) } & \ldots & \ldots & \ldots & \ldots\end{array}$ & 4 & 3 \\
\hline 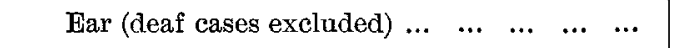 & 7 & 2 \\
\hline Nose and pharynx (adenoid growths) ... ... & - & 2 \\
\hline \multicolumn{3}{|l|}{ General diseases. } \\
\hline $\begin{array}{llllllllll}\text { Measles } & \ldots & \ldots & \ldots & \ldots & \ldots & \ldots & \ldots & \ldots & \ldots\end{array}$ & 16 & 21 \\
\hline $\begin{array}{lllllllll}\text { Scarlet fever } & \ldots & \ldots & \ldots & \ldots & \ldots & \ldots & \ldots & \ldots\end{array}$ & 6 & 12 \\
\hline $\begin{array}{llllllllll}\text { Fever }(?) & \ldots & \ldots & \ldots & \ldots & \ldots & \ldots & \ldots & \ldots & \ldots\end{array}$ & 2 & - \\
\hline $\begin{array}{llllllllll}\text { Typhoid } & \ldots & \ldots & \ldots & \ldots & \ldots & \ldots & \ldots & \ldots & \ldots\end{array}$ & - & 3 \\
\hline $\begin{array}{lllllllll}\text { Diphtheria } & \ldots & \ldots & \ldots & \ldots & \ldots & \ldots & \ldots & \ldots\end{array}$ & 3 & 1 \\
\hline 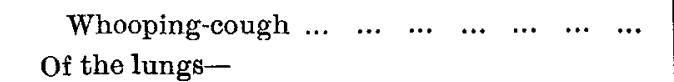 & Of the lungs- & 11 \\
\hline $\begin{array}{rrrrrrrrr}\text { Bronchitis } & \ldots & \ldots & \ldots & \ldots & \ldots & \ldots & \ldots & \ldots\end{array}$ & 6 & 10 \\
\hline $\begin{array}{llllllllll}\text { Pleurisy } & \ldots & \ldots & \ldots & \ldots & \ldots & \ldots & \ldots & \ldots & \ldots\end{array}$ & - & - \\
\hline $\begin{array}{lllllllll}\text { Pneumonia } & \ldots & \ldots & \ldots & \ldots & \ldots & \ldots & \ldots & \ldots\end{array}$ & 2 & $=3$ \\
\hline $\begin{array}{lllllllll}\text { Of the heart } & \ldots & \ldots & \ldots & \ldots & \ldots & \ldots & \ldots & \ldots\end{array}$ & 4 & 6 \\
\hline $\begin{array}{lllllllll}\text { Of the kidney } & \ldots & \ldots & \ldots & \ldots & \ldots & \ldots & \ldots & \ldots\end{array}$ & 1 & - \\
\hline $\begin{array}{lllllllllll}\text { Rickets } & \ldots & \ldots & \ldots & \ldots & \ldots & \ldots & \ldots & \ldots & \ldots & \ldots\end{array}$ & 1 & 7 \\
\hline $\begin{array}{llllllllll}\text { Cretinism } & \ldots & \ldots & \ldots & \ldots & \ldots & \ldots & \ldots & \ldots & \ldots\end{array}$ & - & 1 \\
\hline $\begin{array}{llllllllll}\text { Tubercle } & \ldots & \ldots & \ldots & \ldots & \ldots & \ldots & \ldots & \ldots & \ldots\end{array}$ & 4 & 8 \\
\hline $\begin{array}{lllllllll}\text { Rheumatism }^{*} & \ldots & \ldots & \ldots & \ldots & \ldots & \ldots & \ldots & \ldots\end{array}$ & - & - \\
\hline \multicolumn{3}{|l|}{ Skin disease- } \\
\hline 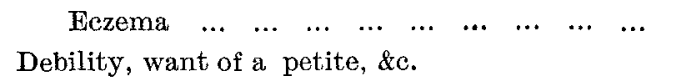 & - & 2 \\
\hline Debility, want of a petite, $\&$ c. & 8 & 9 \\
\hline
\end{tabular}

* See Chorea and Heart Disease.

probable that this was the only cause of the child's condition. Among the London cases two only have this as the sole assigned cause, though it appears in other cases in a 
different form, a not unusual combination being "intemperance of father, and his brutality to mother during pregnancy."

Twin birth.-In one instance in Leicester and in one in London this cause was assigned. Twins are frequently srmall and ill-nourished.

Injury to mother during pregnancy.-This is not stated in any of my cases. Four of the London cases are stated to have this cause. It is well known that abortion may be caused, or the placenta be partially or wholly detached, by injury causing death or serious malnutrition of the fœtus, and one can easily see the method by which this cause might obstruct brain development.

F'right to mother.-Of the Leicester cases two were assigned to this cause, as were also two of the London cases. In one of my cases the father was insane; in the other the child had also had an injury to the head at the age of three and a half years. This cause is so mixed up with the much debated subject of maternal impressions that I have great doubt of its validity, unless there has been actual physical injury at the same time.

\section{Natal Causes arising at the Time of Birth.}

Premature birth.-This accounts for one case in Leicester and one in London. My case was evidently that of a very feeble child, for she did not walk or talk till the age of five years; she is deaf and speaks badly, but is not imbecile and profits by instruction. The arrest of cerebral development from this cause is easy to understand.

Iingering labour. - This was given as the cause of two London cases. Direct injury to the brain, rupture of vessels, and hæmorrhage, meningeal or otherwise, would probably be produced. Cyanosis, if recovered from, would probably not cause arrest of brain development. But stoppage of circulation might cause very serious lesions in nerve tissue. ${ }^{9}$

\section{Post-Natal CaUses.}

Injury to the brain.-Of this condition there were two cases among those from Leicester and two among the London cases. These require no remark, nor do those due to serious injury to the eyes or the body generally. Immersion in water, causing shock and subsequent pneumonia, is given in one of the London cases.

\section{DisEaSES OF THE BRAIN.}

Inflammation of the brain.-This was alleged as to three London cases. It was impossible to inquire into them, but of course meningitis would naturally interfere with sub. sequent development.

Hydrocephalus. - I observed this in three cases. The heads were very large. The process appeared to have been arrested in all. It is impossible to say what the condition was due to. Probably to posterior basic meningitis. Tuberculous would not have been likely to be recovered from. There was one case from this cause among those from London.

Epiltpsy.-There were nine Leicester cases and eight London cases. This cause is so well recognised that I need not say much about it. It must be remembered that the above small numbers only apply to the cases where heredity was not present or could not be proved, and that there were many other epileptics. The extent to which the mental capacity was affected by this disease varies much; some who only had an occasional fit were bright and learned well, while others who had frequent attacks were very dull.

Convulsions in infancy. - This was asserted to be the cause in six of my cases and in 10 of the London cases, or 7.9 and 6.9 per cent. respectively. The coincidence in the numbers is remarkable and shows, I think, that this is a real cause. I do not suppose that the causes of the convulsions are always identical. Some, no doubt, came on in the course of acnte diseases or teething, while others might be true epilepsy now in abeyance and likely to appear again. The children in whom this cause only was alleged were, as a rule, not badly deficient mentally.

Chorea.-I have included this under brain disease as it is almost certain that the incidence of the toxin or bacillus, whichever it may prove to be, is mainly on the cerebral cortex, and this being so it is not surprising that its occurrence during the developmental period should cause mental defect, at all events for a time. Three of my cases and three of the London cases were due to it. An interesting question

9 Experiments on Spinal Cords by Ehrlich and Brieger (Pierre Marie Diseases of the Spinal Cord, New Sydenham Society's Translations, 1895, p. 401). arises here as to whether some of the cases termed developmental and due to this cause among others may not really be true psychoses. I have recently seen a case of well-marked melancholia following an acute attack of chorea and another of chronic mania or dementia, and I shall later relate the case of a patient (Case 7) and give reasons for thinking that his deficiency may be due to dementia coming on at the age of tive years after chorea.

Hamorrhage into the brain or its membranes.-This is a rather frequent cause of mental deficiency. I found it in four of my cases and it was present in four of the London cases. Late contracture made cripples of these subjects. The mental defect was not severe in most of them. Whoopingcough was the cause of the hæmorrhage in one case. In two cases the children were the offspring of elderly mothers of the ages of 43 years and 41 years respectively at the time of the birth of the children. In all these cases there had been a distinct seizure or fit.

Defeot of speech-area of the brain. - In Leicester there were two cases. I expect that these were really from the same cause as the last group, but I have no history of a distinct fit or seizure. The speech was very imperfect in both cases and there was impaired power of movement of the tongue in one case and of the lips in another. In neither was there anything like aphasia.

With regard to diseases of the spinal cord there was one case of Friedreich's disease and that was a London case.

The following are the returns of the diseases of the organs of special sense. From Leicester there were four eye cases and seven ear cases, and from London there were three of the former character and two of the latter, as well as two case of disease of the pharynx and nose (adenoids). These are obvious causes of backwardness and perhaps of arrest of brain development in children. They do not call for much discussion. Many of the ear cases appear again under the headings of measles and scarlet fever. Blind and deaf cases are excluded, being all in special schools. The reason for the absence of cases with adenoids from the Leicester returns is special. The vice-chairman of the school board is Dr. F. W. Bennett, aural surgeon to the Leicester Infirmary, and he has taken great pains to have all such cases treated, with the best possible results. No doubt many more cases of backwardness from this cause existed before attention was so much directed to this condition.

\section{GFNERAL DisEasES.}

This group corresponds to some extent to Dr. G. E. Shuttleworth's post-febrile group, but only partially. He, dealing with the more severe cases of idiocy and imbecility, has in his mind the cases where, as a result of the poison of one of the exanthemata, sclerosis with atrophy, or thickened and adherent membranes, following meningeal inflammations, were produced. I have no doubt that in some of my worst cases this may have occurred. In others, however, I consider that the brain has been affected along with, and in proportion to, the rest of the body, and that as a rule in this group of cases the cause assigned has been a secondary one, the primary or rather predisposing cause being the original weakness of the organism as a whole, due to pre-natal canses, especially to birth from an old and exhausted ovary.

Measles.-This disease appears more frequently than any other. There were 16 cases from Leicester and 21 from London. In several of the cases-one in four out of those from Leicester--there was some deafness due to middle-ear suppuration, but in others, though there was sometimes a discharge from the ear, there was no actual impairment of hearing. So common a disease as measles cannot be credited with being the sole cause, but along with the other exanthemata it is, I believe, a secondary cause in many instances. In several cases where there has been hereditary mental weakness imbecility appears to have followed an attack of measles.

Scarlet fever. - Of cases from Leicester there were six, and of London cases there were 12. Much the same remarks as those on measles apply to scarlet fever.

Of fever (indefined) there were two cases, both being from Leicester; while of typhoid fever there were three cases, all of which were from London.

Diphtheria.-From Leicester there were three cases, and from London there was one case. Apparently diphtheria is not a frequent cause. There has been much diphtheria in Leicester during the last few years.

Whooping-cough.-There were several cases of whoopingcough among those from Leicester, and they were generally in conjunction with measles or lung affection From London 
there were 11 cases. I have mentioned this complaint as leading to cerebral hæmorrhage in one case.

Bronohitis.-The Leicester cases were six in number and those from Loudon numbered 10. As far as I can ascertain, the bronchitis which is credited with producing mental defect is the rather dry, chronic, inherited form. The repeated attacks seem to interfere with cardiac action and circulation, as well as with proper blood aeration. It must not be forgotten, however, that such a complaint interferes very much with proper school attendance, and hence backwardness results, intensifying the effects of any cerebral maldevelopment.

There were two cases of pneumonia from Leicester and three from London.

Heart disease.-Leicester, four cases; London, six cases. In a few cases the condition was congenital ; in others it was due to rheumatism.

Kidney disease. - There was one case of chronic nephritis after scarlet fever.

Rickets.-Leicester, one case ; London, seven cases. I expected to find this a much more constant cause, and, indeed, in a few cases besides the one enumerated the skull was bossed, but I could not satisfy myself that there was any enlargement of the ends of the long bones or of the ribs. Also rickets is not a common disease in Leicester. The milksupply is good and cheap and overcrowding in houses is uncommon.

Cretinism.-I do not know why none of the Leicester children and only one of those from London were cretins. There must be some that have escaped the school board net. The condition needs no remark, its effect on the brain being so well known.

Tubercle.-Leicester, four cases; London, eight cases. In some of its numerous forms tuberculous disease is responsible for a good many defective children. It must be remembered that many of the sufferers from tubercle are much too $i l l$ for any question of school attendance to arise. The cases which I have seen are mostly those of old bone disease.

Rheumatism.-When this is a cause it is usually through its secondary results of cardiac disease or chorea, which have been discussed.

Skin diseases. - There were two cases of eczema among the London cases. Probably this caused backwardness from the children being prevented from attending school; sometimes these cases are coincident with bronchitis.

Debility, want of appetite, \&o.- Some of these cases have been included under other heads, but there appears to be a certain proportion of children who are extremely weak and who resemble the prematurely born. Some of these may possibly be tuberculous cases. Inability to eat breakfast is alleged about many of these.

\section{Tuberculous Family History.}

In addition to those diseases from which the children have suffered or are actually suffering there is the question of those cases noticed by Shuttleworth and others where there exists a history of tubercle in the family. In children of such families there is a want of resistance to the invasion of the tubercle bacillus and often to that of other microorganisms, the germ of the exanthemata particularly. Such a hereditary condition as this has many points of similarity with that which I am about to describe and which I consider to be the most frequent predisposing condition of all-namely, the age of the mother at the birth of the child. Many of these causes will be found to coincide closely with those of idiocy given by Fletcher Beach and Shuttleworth, ${ }^{10}$ and one observation of theirs is worth notice. They say: "Experience teaches that it is rarely scientific to assign one specific cause to a particular case. When it is possible thoroughly to investigate the history many contributing factors may be usually discovered." The age of the mother at the birth of the child is not noticed as a contributing factor.

Age of the mother.-As the forms relating to the family history of the defective children state the ages of the father and mother, the age of the latter at the birth of the child is known. I was struck by the fact that the age of the mother appeared to be excessive in many cases. I then tried to ascertain the average age of the child-bearing woman. This I found to be very difficult. The Registrar-General's returns do not give the ages of mothers at the birth of their children. Statistics exist of the ages of women at the time of delivery from many lying-in institutions in various parts of the world, and these show that a very great majority of the patients in those hospitals were under the age of 30 years at the time of delivery. There are, however, many objections to accepting these statistics as representing the state of matters with regard to the general population. Many of the births in lying-in hospitals are those of illegitimate children, and many others are cases in which women have contracted early and imprudent marriages, and the proportion of primiparæ to multiparæ is very high. The result is that in these institutions more children are born to women under 30 years of age than is the case throughout the entire population. I found, however, some facts reported by Dr. Matthews Duncan, ${ }^{12}$ which were taken from a population resembling in many particulars those of Leicester and London, whence my statistics were derived. The ages of mothers at the time of delivery were stated in the Registrar's returns from the cities of Edinburgh and Glasgow between the years 1850 and 1860 . I have taken these for comparison. I give shortly Dr. Duncan's remarks on these statistics :(1) that the actual, not the relative, fertility of our female population as a whole at different ages increases from the commencement of the child-bearing period of life until the age of 30 years is reached and then declines to its extinction with the child-bearing faculty ; (2) that the actual fertility is much greater before the climax, 30 years, is reached than after it is passed; and (3) that at least three-fifths of the population are recruited from women not exceeding 30 years of age. Dr. Duncan gives his figures distributed in quinquennial periods and I have tabulated my own cases in the same manner (Table II.). Taking all my cases where heredity

TABLE II. - Showing the Relative Ages of Mothers of Normal and Backward Children.

\begin{tabular}{|c|c|c|c|c|c|c|c|}
\hline- & $\begin{array}{l}\text { Under } \\
25 \\
\text { years. }\end{array}$ & $\begin{array}{l}25-29 \\
\text { years. }\end{array}$ & $\begin{array}{l}30-34 \\
\text { years. }\end{array}$ & $\begin{array}{l}35-39 \\
\text { years. }\end{array}$ & $\begin{array}{l}40-44 \\
\text { years. }\end{array}$ & $\begin{array}{c}\text { Over } \\
45 \\
\text { years. }\end{array}$ & Total. \\
\hline \multicolumn{8}{|l|}{ 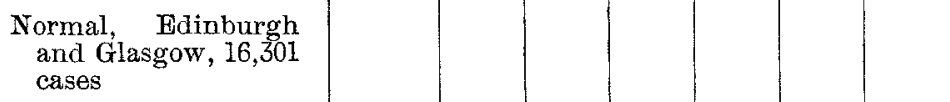 } \\
\hline Per cent. $\quad \ldots \quad \ldots$ & $24 \cdot 92$ & $30 \cdot 89$ & $23 \cdot 61$ & $14 \cdot 76$ & $5 \cdot 15$ & 0.61 & 100 \\
\hline $\begin{array}{l}\text { Leicester, not heredi- } \\
\text { tary-No. of cases... }\end{array}$ & 14 & 14 & 18 & 13 & 14 & 3 & 76 \\
\hline Per cent. $\quad \ldots \quad \ldots$ & $18 \cdot 4$ & $18 \cdot 4$ & $23 \cdot 7$ & $17 \cdot 1$ & $18 \cdot 4$ & $4 \cdot 0$ & 100 \\
\hline $\begin{array}{c}\text { Leicester, bereditary } \\
- \text { No. of cases ... ... }\end{array}$ & 8 & 8 & 5 & 3 & 3 & 0 & 27 \\
\hline Per cent. $\quad \ldots \quad \ldots$ & $29 \cdot 6$ & $29 \cdot 6$ & $18 \cdot 6$ & $11 \cdot 1$ & $11 \cdot 1$ & 0 & 100 \\
\hline $\begin{array}{l}\text { London, not heredi- } \\
\text { tary-No. of cases... }\end{array}$ & 26 & 40 & 47 & 24 & 11 & 3 & 151 \\
\hline Per cent. $\quad \ldots \quad \ldots$ & $17 \cdot 2$ & $26 \cdot 4$ & $31 \cdot 1$ & $16 \cdot 0$ & $7 \cdot 3$ & $2 \cdot 0$ & 100 \\
\hline
\end{tabular}

has been excluded, instead of two-thirds of the children being born when their mothers were under the age of 30 years I find in the Leicester cases that the proportions have been very nearly reversed and that almost two-thirds were born to mothers over 30 years of age, and that 40 per cent. were born to mothers over 35 years of age instead of 20 per cent. as in the normal population, or exactly double. As justifying the exclusion of the hereditary cases these latter approach the normal very closely. The above has reference to the cases observed by myself. The London cases (151), where the facts were ascertained by independent observers, show the point almost as strongly. 40 per cent. are the children of mothers under the age of 30 years and 60 per cent. those of mothers over that age. I believe that if inquiries as to heredity had been pushed further the proportions would have been the same as in the Leicester cases. One difference between the London statistics and those of Leicester is that there are more cases at the ages of from 30 to 34 years and fewer at those from 40 to 44 years. This, I think, may be due to the fact that the London women inhabiting Southwark and Clerkenwell, the districts in which the children lived, undoubtedly "age" more rapidly than do women in a comparatively healthy provincial town like Leicester. I do not believe that such facts with regard to 227 admittedly defective children can be accidental, and there are several further reasons for thinking that advanced age in the mother has an important bearing on the health of her offspring.

Other facts bearing on the importance of the age of the mother. - This is not altogether a new observation. Not to 
go so far back as "Little Benjamin," the youngest of a family of 12 , or to Aristotle who remarks that the young of very old parents are deficient in body and mind, we find a recognition of the fact in provincial speech: there is a dialect word used in Leicestershire and other counties to denote the smallest animal in a litter, and also the youngest weakly child of a family-dilling, often pronounced dillon. ${ }^{12}$ Dr. A. M. Mitchell ${ }^{13}$ quotes a series of 85 idiots and finds that while many of them were children of first pregnancies a much greater number were the children of the eighth, ninth, and subsequent pregnancies than would have been the case in the same number of children with normal brains; also that nearly 25 per cent. were born of mothers between the ages of 40 and 44 years, instead of 5.15 per cent. which would be normal. Shuttleworth ${ }^{14}$ in discussing the Mongol or Kalmuck type of idiot remarks that almost half of the representatives of this type are the last born of a long family. Of course, this implies considerable age in the mother. My observations confirm these remarks, but though it is common to find that the defective child is the last of a large family the family is not always large nor is the child always the last one. Taking 18 children whose mothers were over 35 years of age at their birth at haphazard I find the size of the families to be eight, five, three, 10, 10, five, seven, five, four, seven, six, six, seven, $12,15,10,11$, and eight, six of the families being over 10 in number and 12 being less than that number. All these children except two were the youngest of their families. With regard to one or two general diseases the same cause has been referred to. Dr. A. Carroll and Dr. C. Morley Phillips, ${ }^{1 \overline{5}}$ treating of the causes of rickets, state that it is a recognised fact that a mother advanced in life, even though she has not had numerous previous confinements, is more apt to produce rickety children than is a younger woman. One point more should be considered. It may properly be argued. How do you explain the fact that there are so many cases in children of mothers under 25 years of age? In answer I must first state my general conclusion. It is that the above statistics appear to show that the most frequent causes of defective mental states in children who have no family history of hereditary brain disease are (1), as a predisposing cause, birth from a comparatively aged mother, and (2), as an exciting cause, some acute illness, most frequently one or more of the exanthemata, to which infections children of elderly mothers appear to be particularly liable.

Analysis of causes in children of younger mothers. - I am now in a position to discuss the reason why so many of these children are born of younger mothers. It is clear that certain post-natal causes are sufficient to cause mental deficiency in any child, healthy or otherwise, and my main contention is that the age of the mother produces in children the liability to be affected by causes which would not produce mental deficiency in healthier ones. (Tables III. and IV.) On the examination of the causes given as to children of mothers under 25 years of age we find that acute post-natal diseases are only alleged in five cases out of 13, while in those of mothers over 40 years of age we find acute post-natal diseases accounting for 12 cases out of 17. I think this very suggestive of the truth of my conclusion. In the London cases this is more marked, for acute exanthemata are a cause in the children of mothers under 25 years of age in only $15 \cdot 14$ per cent., while in those of mothers over the age of 35 years they are so in 45.1 per cent. Thus we find that when we are dealing with the children of younger mothers the causes of their mental defect are most frequently such as twin birth, premature birth, inflammation of the brain, accident to the mother, injury to the head, and cretinismall causes which do not require a predisposing weakness of the child in order to produce mental deficiency; while in those of older mothers, these causes not being absent, we find in addition a large proportion in which the mental deficiency has been produced by such causes as acute post-natal diseases, which when attacking the stronger children of younger mothers have no such effects on the brain. It is to be regretted that the London School Board have recently omitted from their family history forms the ages of the fathers and mothers of the children, the importance of the age of the latter having evidently not been brought prominently before them. I now append a few typical cases.

12 Skeat: Fnglish Dialect Dictionary

13 Elinburgh Medical Journal, January, 1886.

Mentally Deficient Children, second edition.

15 Brit. Med. Jour., Sept. 21st, 1895.
TaBLE III.-Causes of Mental Defect in the Children of Mothers under 25 Years of $\mathbf{A g e .}$

LEICESTER (13).

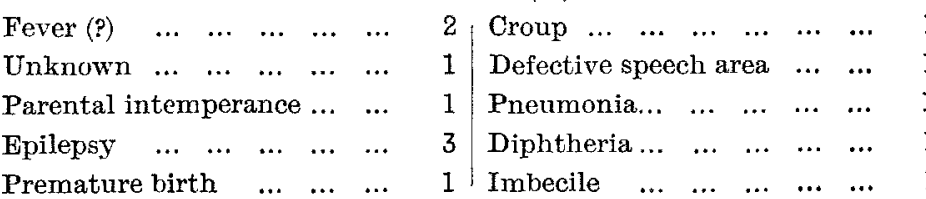

$\begin{array}{llllllllllll}\text { Premature birth } & \ldots & \ldots & \ldots & 1 & \text { Imbecile } & \ldots & \ldots & \ldots & \ldots & \ldots & 1\end{array}$

\begin{tabular}{lllll|lllllll} 
Age of father $(?)$ & $\ldots$ & $\ldots$ & $\ldots$ & 1 & Bronchitis & $\ldots$ & $\ldots$ & $\ldots$ & $\ldots$ & $\ldots$ & 3
\end{tabular}

\begin{tabular}{lllllll|lllll} 
Chorea $\ldots$ & $\ldots$ & $\ldots$ & $\ldots$ & $\ldots$ & $\ldots$ & 1 & Injury to head $\ldots$ & $\ldots$ & $\ldots$ & $\ldots$ & 1
\end{tabular}

\begin{tabular}{lllllll|llllll} 
Unknown & $\ldots$ & $\ldots$ & $\ldots$ & $\ldots$ & $\ldots$ & 4 & Convulsions & $\ldots$ & $\ldots$ & $\ldots$ & $\ldots$ & 1
\end{tabular}

\begin{tabular}{llll|llllllll} 
Inflammation of brain & $\ldots$ & $\ldots$ & 3 & Operation & $\ldots$ & $\ldots$ & $\ldots$ & $\ldots$ & $\ldots$ & 1
\end{tabular}

\begin{tabular}{llll|llll} 
Accident to mother... & $\ldots$ & $\ldots$ & 1 & Congenital cataract & $\ldots$ & $\ldots$ & 1
\end{tabular}

$\begin{array}{lllllllllllll}\text { Pneumonia ... } & \ldots & \ldots & \ldots & \ldots & 1 & \text { Heart disease } & \ldots & \ldots & \ldots & \ldots & 1\end{array}$

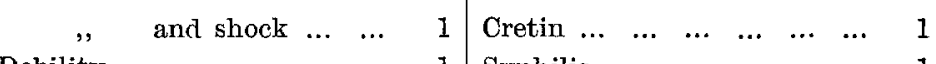

\begin{tabular}{lllllll|llllllll} 
Debility & $\ldots$ & $\ldots$ & $\ldots$ & $\ldots$ & $\ldots$ & 1 & Syphilis & $\ldots$ & $\ldots$ & $\ldots$ & $\ldots$ & $\ldots$ & 1
\end{tabular}

TaBLE IV._Causes of Mental Defect in Children of Mothers. over 40 Years of Age at Birth (18).

LEICESTER.

\begin{tabular}{lllllll|llllll} 
Epilepsy & $\ldots$ & $\ldots$ & $\ldots$ & $\ldots$ & $\ldots$ & 1 & Spastic paraplegia & $\ldots$ & $\ldots$ & $\ldots$ & 1
\end{tabular}

$\begin{array}{llllllllllllll}\text { Imbecile } & \ldots & \ldots & \ldots & \ldots & \ldots & 2 & \text { Measles } & \ldots & \ldots & \ldots & \ldots & \ldots & 4\end{array}$

\begin{tabular}{lllllll|lllllll} 
Unknown & $\ldots$ & $\ldots$ & $\ldots$ & $\ldots$ & $\ldots$ & 2 & Bronchitis & $\ldots$ & $\ldots$ & $\ldots$ & $\ldots$ & $\ldots$ & 3
\end{tabular}

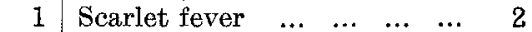

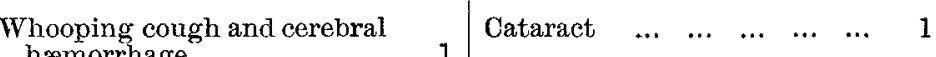

hæmorrhage $\ldots \quad \ldots \quad \ldots \quad \ldots$

CASE 1. Birth from a mother advanoed in years; measles ; abscess of the ears. - The age of this child was nine years and nine months, and he was the youngest of eight children. His mother was aged 38 years at his birth, the father being of the same age. The boy's head was small and his expression was stupid. The palate was normal, the teeth were fair, the lobes of the ears were adherent, and the features were rather coarse. There was some corrugation of the forehead and the head was held rather on one side. The hands were normal in shape and the position when they were extended was normal. There was a good deal of twitching of the body when the boy was standing still. He had had measles severely in infancy, followed by abscess of the ears. He commenced to walk at the age of two years and to talk half a year later. In measurement he was two inches below the normal and he was two pounds under the normal weight. He could name objects well and he knew the day of the week. He could read a few short words, could write down badly words of three letters from dictation, could do a very simple addition sum but no subtraction, and was now (but only lately) fairly quick at manual work. His attention wandered very much and his memory was bad. He could not be trusted to perform an errand correctly. He was improving under special treatment, which be had been undergoing for a year. This is a typical case.

CASE 2. The mother of advanced age; rickets; measles.In this case the child was of the age of seven and a half years and she was the sixth child, there being an interval of 11 years between the next oldest and herself. At the time of her birth her mother was 41 years of age and her father was of the same age. Her head measured 20 inches and there were frontal and occipital bosses. The palate was normal, the teeth were bad, and the lobes of the ears were adherent, but the features were fairly good. She weighed four pounds less and measured two inches less than the normal. Her face twitched slightly, but the pose of the head was normal. The hands were normal in shape but the fingers were over-extended. The body was normal and she was cleanly in her habits. She had suffered severely from rickets, she walked badly, and she had had bronchitis and measles. She talked at one and a half years and walked at three vears of age. Her powers of observation were weak, but she could name objects, and she knew the day of the week, could read words of three and four letters, and could write words of three letters from dictation. She had no idea of numbers. She had improved under special training for one year, but still she had no idea of numbers. This was not such a severe case as the previous one

CAsE 3. Delicate; bad eyesight.-This child was eight years of age and was the twelfth or thirteenth of a family of 16 children. When she was born her mother was 35 . 

years of age and her father was the of same age. Her
head measured 17 inches. Her expression was vacant, the palate had rather a high arch but was not narrow, the teeth were fair, the ears were badly shaped and rather pointed, and the features were coarse. She was five inches in measurement and 19 pounds in weight below the normal standarl. She had small thin hands which presented a drooping position when extended. In her habits she was cleanly but she was always cold and had never been well. Her eyesight was bad and she was slow in her movements. She walked and talked at the age of two years. She imitated movements slowly, rearl fairly, wrote very badly, and could only calculate up to four, but she could do manual work. Her health was very defective and her sight had also prevented the development of intelligence.

CASE 4. The youngest of 16 children; bronchitis.-This child, who was seven and a half years of age, was one of 16 children, most of whom had died in infancy, several from bronchitis. The mother was 41 years of age at the time of the birth of this child and the father was

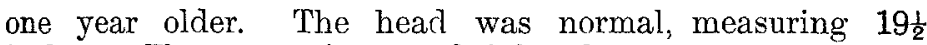
inches. The expression was bright, the palate was normal, the teeth were good, the ears were normal, and the features were good. In height she was two inches above and in weight two pounds below the normal. 'The head was held on one side. 'I'he hands were normal in shape and pose. There was some twitching of the body. Her habits were cleanly. She had suffered much from bronchitis. The father had chronic bronchitis and he had had dry eczema. She looked a bright girl, but was not too strong in the moral sense. She could only read, write, and count in the most rudimentary way but she coulrl do manual work fairly well. This child would have quite escaped all notice on Dr. Warner's plan of examination. Not any of his developmental or nervous signs were present, ret she was very defective.

CASE 5. The mother of advanced age; bronchitis. - The age of this child was seven years. At the birth of the child the mother was 42 vears of age and the father was of the same

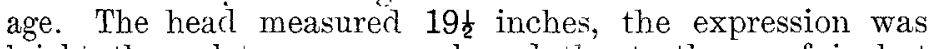
bright, the palate was normal, and the teeth were fair, but the ears were not of good shape. In height the child was four inches and in weight nine pounds less than normal - a very small, delicate-looking child. Severe attacks of bronchitis had been experienced. The child's habits were cleanly. Objects were named with difficulty and the day of the week could not be told. The child could only read words of two letters, could hardly write anything, and counting was very deficient, but the moral sense was good.

CASE 6. The mother advanced in years; chorea.-This child, the ninth of 11 children, was of the age of seven and a half years. The two children who were younger than himself had died from tubercle of the abdomen (?). The mother was 37 years of age at the birth of the child and the father was 39 years of age. The boy's expression was dull, the palate had rather a high arch but was not narrow, the teeth were fair, the ears were coarse and they stood out, and the nose was broad. The height and weight of the child were normal. The head was held on one side, the hands were badly formed, and there was weakness in the pose as well as restlessness. He had had chorea three times. The memory was fair and he could read short words, count a little, and do manual work. He was a very nervous child, but his condition was better than was that of the other children whose cases I have reported and he ought to do well.

The last case is one to which I have already referred as being probably psychosis and not entirely a case of arrest of cerebral development.

CASE 7. This boy, when I first saw him six months ago, was $11 \frac{1}{2}$ years of age. His head, which was narrow, measured $20 \frac{1}{1}$ inches. At his birth bis mother was 45 years of age and his father's age was 48 years. He had a sullen and dull expression. The palate was normal, the teeth were good, the ears were normal, but the features were rather coarse. In height he was one and a half inches and in weight five pounds under the normal. He squinted slightly. The head was fixed and the hands were weak in pose. He had har measles and scarlet fever at the age of four years, followed by left hemichorea, which had existed ever since more or less till recently. Two years previonsly he was pronouncer to be an idiot by the medical attendant of the family. I certified him to be an imbecile. He could not name objects, could not read any letters or write, would not answer a simple question, and was reported to lie, to steal, and to be uncleanly in his habits, and also to wander about the streets and to lose himself. Now be certainly is not an imbecile; he can be entrusted to carry out an errand, can name objects well, can answer questions, does not wander about or steal, and is cleanly in his habits. Such improvement, morally as well as mentally, indicates to me that this was a case of dementia following chorea. I have lately met with two similar cases-one of typical melancholia and the other of chronic mania or dementia-following the same primary disease. In this case I have no doubt the weakness of constitution derived from the excessive age of the mother predisposed to the mental affection.

To sum up, the most careful observers divide the causes of mental weakness into pre-natal, natal, and post-natal. With regard to the two latter groups my cases fall in with those given by other observers, notably Beach and Shuttleworth. ${ }^{\text {is }}$ They, however, are evidently much impressed with the fact that in most cases there is a congenital weakness of constitution which, when acted upon by post-natal causes, induces the maldevelopment of the brain. Even in their more serious cases of idiocy and imbecility, however, they are only able to point to somewhere about 40 per cent. in which there was a family history which would account for such defect. I claim that the excessive age of the mother will account for such congenital, though not hereditary, influence in from 60 to 70 per cent. of the remainder.

Dr. Warner has so kindly placed all the information which he possesses at my disposal that I feel very reluctant to call his conclusions in question. There are, however, one or two points in which my results differ from his and which I should like to indicate. In the first place, as I have already stated, all the observations on the 100,000 children in the report ${ }^{7}$ are based on the assumption that it was impossible to ascertain facts as to family history and that it was also impossible to make physical examinations of the children. Under the new Act these are now both possible. Next, the statement is made: "It is in the co-relation of abnormalities in the proportion of parts of the body, with abnormal nerve signs, low nutrition, and mental dulness that we find a criterion of the really defective status connected with the abnormality and the value of such signs." is I am not sure that I understand this, but $I$ take it to mean that there is some defect in the brain in these cases that we cannot detect by taking the ordinary methods of ascertaining the child's mental faculties. To this I cannot assent. It appears to me that we can ascertain the state of development of a child's brain at least as well by asking such child to name objects or by testing the memory, \&c., as by looking at the cranium, palate, hands, \&c., and co-relating any malformation of these with corrugated superciliary muscles, open mouth, or twitching fingers. I do not wish to say that the results of the examination of so many children are useless; no such accumulation of facts can fail to be useful at some time or another to someone, but when Dr. Warner ${ }^{19}$ states that "by the analysis and study of such observations we are enabled to determine the causation and the treatment of mental diseases" I think he goes beyond his facts. What are the signs on which he relies? ${ }^{20}$ The first is that of the defects in development of the body and its parts in size, form, or proportion, "such signs appear to indicate inborn and fixed constitutional tendencies." This is the doctrine of stigmata, and I take leave to say that it is wholly unproven. No one will deny that a child with a very imperfect brain may happen at the same time to have an imperfectly developed body and mav even be likely to have this, but I do deny that bodily imperfections are, as a rule, an index of brain development. Phrenology we have discarded. We have Socrates to quote, or rather Plato, against the thecry that the face is an index of the minr, and I will now state a few facts with regard to two of the supposed defects.

The cranium. - The measurement of the cranium is proverbially difficult. The direction given by the committee ${ }^{21}$ is that heads less than 19 inches in circumference after three years of age are to be considered small. I venture to think that a careful inspection of any hatter's stock would show that hard-and-fast lines of this sort are of little value.

The ear.--This, if large and outstanding, or with imperfect helix, is supposed to indicate defect. This is a favourite

1s Clifford Allbutt: A System of Medicine, vol. viii.

17 Report on the Scientific Study of the Mental and Physical Conditions of Childhood (Charity Organisation Society, 1895).

$$
19 \text { Clifford Allbutt: A System of Medicine, vol. viii., p. } 198 .
$$$$
20 \text { Ibid., p. } 199
$$$$
21 \text { Ibia., p. } 20 \text {. }
$$ 
subject with a class of writers who resemble those on palmistry, and a work has been written entirely on this subject. ${ }^{22}$ 'The reviewer of this work in Nature, Dr. Keith, ${ }^{23}$ relates how he himself had examined 40,000 ears of dwellers on both sides of the German Ocean in an endeavour to discover if any traces of affinity of race could be found by this means. His results were negative, but he aftirms that he convinced himself that every form of ear may be found in persons of every grade of life and standard of intelligence, and that what has been described with confidence as the "criminal ear" is the normal form for inhabitants of these islands.

The palate.-The shape of the palate has great prominence given to it, and I have consequently made a good many observations with regard to it. The committee state that it has a high pathological co-relation. I found in 80 cases of mental defect that the palate had a high arch in 34, it was doubtfully high in eight, and was normal in 38 . This does not seem a high percentage, and in the seven cases which I report fully, which were selected on quite other grounds and in which I had not specially noticed the condition of the palate, I found five to be normal, one doubtful, and one high. A diagnostic sign which misses five out of seven is not worth much.

I thought it worth while, having the opportunity, to ascertain if this sign and that of nervous pose of the hands were absent from children admittedly not defective, at all events as to their capacity for learning, and I therefore examined 500 children in the fifth, sixth, and seventh standards in the Leicester schools. I found in some of the higher standards examples of the most deformed palates, high-arch, V-shaped, and asymmetrical ; and the totals worked out: examined 500, with high-arched palate 135, with hands of weak balance 126 . Thus showing that half as many in proportion of the brightest children had high palates as the defective ones.

Nerve-signs, so-called, form the second of Dr. Warner's signs. These undoubtedly in many cases are an indication of irregular discharge of muscular impulses, and as such deserve attention ; but many of these, especially the twitching of the face and hands, are really chorea and depend on a definite pathological condition of the cortex, while others are secondary to injuries of the brain or cord (athetosis in birth palsies)

The third sign on which Dr. Warner relies is that of low nutrition. This has in some cases a connexion with the mental enfeeblement. Dr. Warner says : "24 "It is among the children with defects in bodily development that we find the largest proportion of the pale, thin, delicate children whose tissue delicacy is connected in causation with the defective symmetry of features and parts of body." I have already explained that I consider most of the cases of extreme delicacy to arise in the children of old mothers who have been attacked by acute diseases, and this condition is not hereditary in any other sense than that it is partly congenital. I must state here, as I have done previously, that Dr. Warner himself allows that there is a small class of dull children who do not show defect, and that a considerable portion of children showing defects are not mentally dull. I therefore think that while undoubtedly those children with arrested brain development have more frequently than healthy ones signs of abnormal development in other organs, yet these signs are not so much more frequent in them as to give us much help in the diagnosis of the condition, which, moreover, can be readily ascertained by other methods.

\section{CONCLUSIONS.}

If the theory that a very large percentage of those cases can be accounted for by pathological or accidental causes acting on congenital weakness not of an hereditary character is true, does it afford any oround for believing that such conditions are likely either to increase or to decrease? The hereditary cases will no doubt for a long time continue about the same. State regulation of marriage is almost the only measure that could control them, and that appears as yet to be far distant. The law of reversion to type and intermarriage with healthy stock will no doubt prevent their increasing to any great extent, even if they do not diminish. With regard to the children of elderly women I think that some good may be done if it is freely recognised that women who bear more than a moderate number of children run the

sa The Human Far: 1ts Identitication and Pnysiognomy. 22 Nature, vol. lxiii., p. 392. 24 Ibid., p. 199, risk of bringing weakly ones into the world, that the same remark applies to women much over 30 years of age, and that if such children are born they require additional care, and in particular protection from the germs of infectious diseases.

Leicester.

\section{THE TREATMENT OF GLAUCOMA BY EXCISION OF THE SUPERIOR CERVICAL GANGLION OF THE SYMPATHETIC.}

BY A. L. WHTTEHEAD, M.B., B.S. LoND., \&C., OPHTHALMIC AND AURAL SURGEON TO THE GENERAI INFIRMARY AT LEEDS.

Ar the present time, when the advisability of removing the superior cervical ganglion of the sympathetic for glaucoma is under consideration, the following case is of great interest.

A man, aged 23 years, was admitted into the Leeds General Infirmary under my care on Oct. 28th, 1899, for injury to the left eye sustained by the bursting of a sodawater bottle. There was a small lacerated wound at the corneo-scleral junction, into which the base of the iris was prolapsed. The patient was warned of the possibility of sympathetic trouble, but went home as soon as the wound healed and was not seen again until March 31st, 1900. He then returned with intense irido-cyclitis in the left eye and in the right eye marked sympathetic iritis, which had set in three weeks previously to his second admission The left eye was excised, the sight being quite lost, and under atropine, leeches to the temple, \&c., the right eye rapidly improved, the pupil dilated, and the iritis subsided. He went out on May 12th, when the eye was quiet and vision was ${ }^{6}$. On August 11th the man returned, vision having rapidly failed within the previous three weeks. There was then considerable ciliary congestion, the anterior chamber was shallow, the pupil was fixed, and the iris was swollen and acutely inflamed. Tension was +3 and the vision was reduced to ability to count fingers at six inches. Paracentesis of the anterior chamber was performed without giving relief, and three days later iridectomy was attempted but could not be satisfactorily performed, the iris being found to be firmly adherent to the lens throughout its entire breadth. Tension remaining +3 paracentesis was performed on the 29 th and on Sept. 20th, and iridectomy was again attempted on the 29th. On Oct. 3rd sclerotomy was performed; tension, however, rose again to +3 on the following day. On the 7th it was decided to remove the superior cervical ganglion of the sympathetic, which operation Mr. B. G. A. Moynihan at my request performed on the same day. The ganglion was reached through an incision behind the posterior border of the sterno-mastoid, carefully separated from the surrounding parts, and excised.

The immediate effect of the operation was striking, the tension of the eyeball falling rapidly to $+\frac{1}{2}$, although there was no contraction of the pupil, the iris being fixed as described above. The following day (the 8th) tension rose to +2 , but two days later it was $+\frac{1}{2}$ and vision had improved to ability to count fingers at 14 inches. There were slight fluctuations in the tension from day to day, but the improvement in vision was maintained until he left the hospital on the 30th. I saw him again on Jan. 5th, 1901, and found the tension +1 and vision = ability to count fingers at 18 inches. No treatment, local or constitutional, was carried on subsequently to the operation, so that the reduction of tension and improvement in vision must be attributed entirely to the removal of the ganglion.

The effects of the operation are immediate and secondary. The immediate effects are relief of pain in the eye, contrac tion of the pupil when not fixed by adhesions, congestion, and lacrymation of the eye, reduction of tension, and unilateral sweating of the head; the secondary effects are progressive reduction of tension, sometimes preceded by a temporary rise, gradual improvement in vision, slight ptosis, and some sinking of the eyeball into the orbit. The lacry mation, congestion, and sweating usually disappear within 48 hours.

I A paper lean butule the Leeds and West kiding Meulicu-Chin urgical Society on March 15th, 1901. 